\title{
Özel Yetenekli Çocukların Ebeveynlerinin Akılcı Olmayan İnançları ve Ebeveyn Yetkinliklerinin İncelenmesi ${ }^{1}$
}

\author{
DOI: 10.26466/opus.640449
}

*

\section{Yunus Emre Aydın ${ }^{*}$ - Ahmet Buğa ${ }^{* *}$}

* Uzm. Psk. Dan., Şahinbey Rehberlik ve Araştırma Merkezi, Şahinbey/ Gaziantep/ Türkiye E-Posta: pd.yemreaydin@gmail.com ORCID: 0000-0002-6227-4926

** Dr. Öğr.Üyesi, Gaziantep Üniversitesi, Eğitim Fakültesi, Şehitkamil/ Gaziantep/ Türkiye E-Posta: buga@gantep.edu.tr

ORCID: $\underline{0000-0002-9598-2451}$

Öz

$B u$ araştırmada, özel yetenekli çocukların ebeveynlerinin akılcı olmayan inançları ile ebeveyn yetkinliği arasında ilişki olup olmadığg; ayrıca özel yetenekli çocukların ebeveynlerinin akılcı olmayan inançları ve ebeveyn yetkinliklerinin çeşitli değişkenlere göre farklılaşıp farklılaşmadı̆̆ı incelenmiştir. İlişkisel tarama modeli kullanılarak yürütülen araştırmada çalışma grubu, 2018-2019 eğitim öğretim yılında Gaziantep ili Şahinbey Bilim ve Sanat Merkezi'ne kayıtl ilkokul ve ortaokul düzeyindeki öğrencilerin ebeveynlerinden oluşmaktadır. 147 anne ve 126 baba olmak üzere toplam 273 ebeveyn araştırmanın örneklemini oluşturmaktadır. Bu araştırmada kullanılan veriler; Kişisel Bilgi Formu, Anne-Baba Akılcı Olmayan İnançlar Ölçeği (ABAOIÖ) ve Ebeveyn Yetkinlik Ölçeği'nden elde edilmiştir. Araştırma değişkenleri; cinsiyet, çalışma durumu, çocuk okul kademesi, toplam aylık gelir, eğitim durumu açısından incelenmiş olup SPSS programı üzerinden bağgrmsız grup T- testi, tek yönlü varyans analizi (Anova) kullanılmıştır. Özel yetenekli çocukların ebeveynlerinin akılcı olmayan inançları ve ebeveyn yetkinlikleri arasında ilişki olup olmadığııı ortaya koymak için basit doğrusal korelasyon işlemi yapılmış, Pearson Korelasyon Matrisi kullanılmıştır. Araştırma sonucunda; özel yetenekli çocukların ebeveynlerinin akılcı olmayan inançlarmn beklenti alt boyutu ile ebeveyn yetkinliği arasında pozitif yönde ve düşük düzeyde anlaml bir ilişki olduğu tespit edilmiştir. AnneBaba Akılcı Olmayan İnançlar Ölçeği incelendiğinde "Beklentiler" boyutunda cinsiyet ve eğitim durumuna göre; "Mükemmeliyetçilik" boyutunda eğitim durumuna göre anlaml farklllklar tespit edilmiştir. Ebeveyn Yetkinlik Ölçeği'ne göre değiş̧kenler incelendiğinde ise cinsiyet, çalışma durumlarına göre anlaml farklllık tespit edilmiştir. Elde edilen sonuçlar alan yazın ışı̆̆ında tartışılmıştır.

Anahtar Kelimeler: Özel yetenek, Ebeveyn, Akılcı olmayan inanç, Yetkinlik

\footnotetext{
${ }^{1}$ Bu çalışma, 1.yazarın 2.yazarın danışmanlığında Gaziantep Üniversitesi Eğitim Bilimleri Enstitüsü'nde tamamlanan yüksek lisans tezinden üretilmiştir.
} 


\title{
Investigation of the Parents' Irrational Beliefs and Parental Self-Efficacy of Parents of Gifted Children
}

*

\begin{abstract}
In this research, it is investigated whether here is a relationship between gifted children's parents' irrational beliefs and parental self-efficacy. Additively, examined whether there is a differences between gifted children's parents' irrational beliefs and parental self-efficacy, according to some variables. Research model is carried out in survey research model from scientific research methods. The sample group, in the 2018-2019 academic year, it consists of the parents of primary and secondary school students registered to Sahinbey Science and Art Center in Gaziantep. Sample consists 147 mothers and 126 fathers totally 273 members. Personal information form, Parent Irrational Beliefs Scale and Parental Self-Efficacy Scale were used as data collections in this research. Research variables (gender, job status, level of students' grades, income, graduation status) were collected. In analysis of obtained data "statistical program for social science (SPSS)" package program was used. T-test (for unrelated samples), analysis variance for independent samples (ANOVA) were used. To determine whether there is a relationship between gifted children's' parents' irrational beliefs and parental self-efficacy simple linear correlation was used and showed in Pearson Correlation Matrix. At the end of research, there were positive and low level of significant relationship found between irrational beliefs and parental self-efficacy of gifted children's' parents. When Parental Irrational Beliefs Scale is examined, significant differences were found in the "Expectations" sub-dimension according to gender and graduation status and significant differences were found in the "Perfectionism" sub-dimension according to the graduation status. When the variables were examined according to Parental Self-Efficacy Scale, significant differences were found according to gender and working status. Findings were discussed in the light of literature.
\end{abstract}

Keywords: Gifted, Parent, Irrational belief, Self-efficacy 


\section{Giriş}

Çocukların ilk rol-modelleri ve öğretmenleri anne-babalarıdır. Çocuklar onlara yol gösterici konumunda olan anne ve babalarından birçok şeyi taklit ederek öğrenmeye başlar. Çocuklar, anne ve babalarının tutumlarını ve davranışlarının onları örnek alarak öğrenmektedirler (Morgan, 1980, s.323). Anne - baba olmak; çocuğun bakımı, çocuğun korunması, çocuğun eğitimi çocuğun ruh sağlığının zedelenmemesi, çocukla kaliteli zaman geçirme, çocuğun hayatı ve geleceği hakkında doğru kararlar alma, çocukla sağlıklı bir iletişim kurabilme, çocuğa duygusal anlamda destek verebilme, çocuğun masraflarını karşılayabilme ile ilgili olarak ebeveyn sorumluluklarını yükler (Canel, 2012, s.61).

Toplumu oluşturan ailelerin bir kısmı ise, yaşam kalitelerini etkileyen özel durumlarla karşı karşıya kalmaktadır. Bu durumlardan biri de özel gereksinimli bir çocuğa sahip olmadır. Özel gereksinimi olan bireyler ve aileleri her şeyden önce toplumun parçasıdır. Özel gereksinimli çocukların ailelerinin yapıları incelendiğinde, genel nüfus özelliklerine uyumlu oldukları gözlenmektedir. Fakat aileler arasında benzerliklerine rağmen, özellikle yetersizliği olan bireyin farklı gereksinimleri nedeniyle kendilerine özgü özellikler de bulunmaktadır. Özel gereksinimi olan bireylerin gelişiminde rol oynayan etmenleri anlamak için ailenin özel gereksinimli bir çocuğa sahip olduğunda gösterdiği tepkiler, bu süreçteki rol ve işlevlerini yerine getirme durumu, özel gereksinimli çocuğun bakımı ve eğitimine katılımı gibi konuların incelenmesinde yarar vardır (Cavkaytar, 2017).

Özel gereksinimli çocuk; bireysel ve gelişim özellikleri ile eğitim yeterlilikleri açısından akranlarından anlamlı düzeyde farklılık gösteren bireyi tanımlamaktadır. Özel gereksinimli olarak kabul edilen çocuklardan biri de özel yetenekli çocuklardır. Özel yetenekli çocuklar, bir ya da birden çok yetenek alanında ya da zekâ özelliğinde üstün performans gösteren, yaratıcılık, sanat ve akademik alanlarda yaşıtlarına göre yüksek düzeyde performans, motivasyon ve görev sorumluluğu sergileyen ve bu tür yeteneklerini geliştirmek için uygun imkanlara gereksinim duyan çocuklardır (Milli Eğitim Bakanlığı, 2018; Kuzucu, 2014, s.471).

Özel yetenekli bir çocuğun anne- babası olmanın zevkli taraflarının yanı sıra zorlayıcı, kimi zamansa tüketici olabilmektedir. Normal gelişim gösteren çocuğa sahip ailelere göre özel yetenekli çocukların aileleri, ço- 
cuklarındaki gelişimsel özellikler sebebiyle birçok açıdan farklı durumlarla karşı karşıya kalırlar. Anne ve babalara, çocuklarının özel yetenekli olduğu ilk defa söylenildiğinde gurur ve mutluluk gibi duygular aynı anda yaşayabilmelerine rağmen; bu aileler aynı zamanda özel yetenekli bir çocuğu nasıl yetiştirecekleri konusunda kaygı da yaşayabilmektedirler. Pek çok özel yetenekli çocuğun anne ve babası çocuklarının ihtiyaçlarının diğerlerinden farklı olabileceğini anlamakta, aynı zamanda bu zorluklarla başa çıkmada donanımlı olmadıklarını da düşünebilmektedirler. Erken yaşlardan başlayarak özel yetenekli çocukların düşünme biçimlerinin ve davranışlarının tipik olarak ifade edilenlerden farklı olduğu gözlenmektedir. Ebeveynler genellikle özel yetenekli çocuklarını "başa çıkması zor", "güçlü istekleri olan" veya "zorlayıcı" olarak tanımlarlar. Ailelerden daha ayrıntılı olarak açıklamalar istendiğinde ise "inatç", "tartışmacı", "patronluk taslayan", "kendi dünyasında yaşayan", "yargılayıcı", "mükemmeliyetçi", "kendini eleştiren" vb. sıfatları da kullandıkları görülebilmektedir (Akt; Saranlı, 2011; Davis ve Rimm, 2004; Delisle, 2006; Webb vd.,2007). Bu bağlamda ebeveynlerin özel yetenekli çocuğa sahip olmayı bir anlamda zorlu bir görev olarak algıladıkları söylenebilir. Nitekim bu durumun da ailelerin kendi ebeveyn yetkinlikleri konusunda sorgulayıcı bir durum olarak düşünülebilir.

Ebeveyn yetkinliği ise, ebeveynlerin anne ve baba olarak üstüne düşen görevleri ve bu görevleri etkili bir biçimde gerçekleştirebilme düzeyine ilişkin beklentileri ifade eder (Teti ve Genfald, 1991). Bandura (1982) düşük yetkinlik inancının sadece yeni becerilerin kazanılmasını engellemekle kalmayıp, mevcut becerilerin performansını da engelleyebileceğini ifade etmiştir. Bundan dolayı yüksek ebeveyn yetkinliğine sahip anne babalar, yeni bilgi ve becerilerini eyleme geçirme ve bu nedenle çocuklarından önemli düzeyde olumlu dönütler alma olasılıkları yüksektir. Bunun aksine düşük ebeveyn yetkinliğine sahip anne-babalar, yeni bilgi ve becerilerinin kazanılmasını engellemenin yanı sıra kendi ebeveynlik kapasitelerine güven duymayıp, çocuklarından minimum düzeyde dönütler alma olasılığı yüksektir (Coleman ve Karraker, 1998, s.71). Yüksek ebeveyn yetkinliğine sahip anne-babalar hem çevresiyle hem de çocuklarıyla sıcak ilişkiler kurabilen ve çocuklarının da olumlu ilişkiler kurmasını destekleyen bireylerdir (Coleman ve Karraker, 1998). Yüksek ebeveyn yetkinliği olan annebabalar, çocuklarının eğitim yaşantısına aktif rol almaları yönünde inanç- 
lara sahiptirler. Düşük düzeyde ebeveyn yetkinliği olan anne-babalar ise daha az aktif roller sergileyecektir (Hoover-Dempsey ve Sandler, 1997, s.31,32). Grolnick, Benjet, Krowski ve Apostoleris'e (1997, s.544) göre; yetkinlik algısı yüksek olan ebeveynlerin düşük olanlara göre çocuklarının okul sürecine, ev ödevlerinde yardım ederek, zihinsel alanlarda çocuklarlyla ilgilenerek takip etmektedirler. Giallo, Kienhuis, Treyvaud ve Matthews $(2008$, s.45) ise çocuklarının akademik başarılarını yönetme ve destek olma konusunda yüksek yetkinlik algisına sahip olan ebeveynlerin, yetkinlik algısı düşük olan ebeveynlere göre çocuklarının eğitim yaşantılarına daha etkili destek olduklarını ve bu çocukların etkili öğrenme konusunda kendini yönetme becerilerini daha etkili kullandıklarını ifade etmiştir.

Ebeveyn yetkinlik inançları, çocuk bakımı ile ilgili deneyim gibi pozitif ebeveynlik uygulamaları, depresyon, çocuk karakteri, sosyal destek ve sosyoekonomik düzey gibi ebeveyn olmaya ait özelliklerle doğrudan ilişkilidir (Coleman ve Karraker, 1997).Holloway, Suzuki, Yamamoto ve Behrens (2005); ebeveyn yetkinliğinin gelişiminin, ebeveynlerin kendi annebabalarıyla yaşadıkları ilişkinin niteliğiyle, eşlerinden, akrabalarından ve yakın çevrelerindeki diğer insanlardan gördükleri sosyal destekle ve eğitim düzeyleriyle ilişkili olduğunu belirtmiştir. Yüksek ebeveyn yetkinliğine sahip ebeveynler, yetkinlik inancyyla bir arada var olan bilişler umut, olumlu başa çıkma fikirleri ve kendi kendini onaylama eğilimi gibi daha akılcı inançlar yaratma eğilimindeyken; düşük yetkinlik inancına sahip ebeveynler, felaketleştirme, kendini suçlama ve ezici bir boşalma duygusu düşünceleri yani daha akılcı olmayan inançlara sahip olma eğiliminde olabilmektedir (Coleman ve Karraker, 1998, s.70).

Akılcı inançlar; iç tutarlılığı olan mantıksal, deneysel olarak ispatlanabilen, mutlak ve şartsız olmayıp şartlara göre değişebilen (izafi), kişinin hedeflerine ulaşmasında yardımcı olan ve bireyde sağlıklı bir yapı oluşturan düşüncelerdir. Akılcı olmayan inançlar ise daha farklı, genellikle de akılcı inançların zıttı bazı özelliklere sahiptir. Akılcı olmayan inançlar; mantıksal açıdan tutarsız, deneysel gerçekliklere aykırılık gösteren, mutlak ve dogmatik, kişinin hedeflerine ulaşmasını engelleyen, kişiye acı veren ya da işlevselliğini bozan ve bununla birlikte problem çözme becerilerinden mahrum bırakan, bireyde ruhsal rahatsızlık oluşturabilen, sağlıksız bir yapıya sebep olabilen düşüncelerdir (Köroğlu, 2014). Ebeveynlerin akılcı olmayan inançları ile ilgili yapılan bilimsel çalışmalar ışığında anne 
babaların akılcı olmayan inançları ile çocuk yetiştirme tarzları (Hauck, 1967), aile ortamı (Stimac, 1985; Bağcı,2013), ebeveynlik stresi (Joyce,1995; Starko, 1991), stres düzeyi (Pochtar, 2010), çocuklarda gözlenen problem davranışlar (Bağcl, 2013) arasında ilişki olduğunu ortaya koyulmuştur. Ayrıca ebeveynlerin akılcı olmayan ilişki inançları artıkça ergen çocuklarına yönelik çatışma çözme becerileri azalmakta, ebeveyn ve ergen arasındaki ilişki zarar görmektedir (Hamamc1, 2007).

Akılcı Duygusal Davranışçı Terapi' ye göre ebeveynler çocuklarının rol modelleri ve onları pekiştirme-cezalandırma otoriteleri olarak, onların duygusal ve davranışsal sorunlarını en aza indirebilecekleri, önleyebilecekleri gibi bu sorunları daha da etkisini veya şiddetini arttrabilirler. Ellis, ebeveynlerin çocuklarına yapabilecekleri en kötü şeyin çocuklarının yaptıkları hata ve yanlışlarından dolayı onları suçlamak olduğunu ve yaşanılan bu olumsuz durumun sonucunda çocuklarda kendini suçlama, düşük benlik saygısı, anksiyete gibi sorunlar yaşayabileceklerini belirtmiştir (Ellis ve Bernard, 2006, s.10-11). Ebeveynlerin akılcı olmayan bu inançları, çocukların kişilik gelişimini ve ruh sağlığını olumsuz etkileyebilmekte çocuklarının yanı sıra kendilerinin ve ailenin işlevlerini olumsuz etkilemektedir.

Ebeveynlerin, çocuktan ya da anne babalığa dair kendilerinden akılcı olmayan beklentileri onların ruhsal hallerini olumsuz bir şekilde etkilemektedir. Ebeveynlerin, yüksek düzeyde akılcı olmayan inançlara sahip olması onları ruhsal olarak olumsuz etkilemekte ve bu durum da kendilerine ve çocuklarına sağlıklı bir şekilde davranmalarını engellemektedir. Sağlıksız ebeveyn tutum ve davranışları çocukların kişilik gelişimini ve ruh sağlığını olumsuz etkilediğini inceleyen uzmanlar, sağlıklı çocuk yetiştirmenin ancak sağlıklı ebeveynler ile mümkün olabileceğini belirtmişlerdir. Çocukların yaşadıkları ruhsal problemlerin temelindeki önemli bir etken olan ebeveynlerin akılcı olmayan inançlarının tespit edilmesi ve iyileştirilmesi çocuklar, ebeveynler ve toplumun sağlıklı gelişimi açısından önem arz etmektedir (Kaya, 2010). Ebeveynlerin çocuklarına akılcı olan inançlarını yansıtması ve çocukların da bu akılcı inançları örnek almaları sağlıklı bir durumdur. Çocukların ebeveynleri rol model aldığı düşünüldügünde ebeveynlerin akılcı olan inançlara sahip olmaları, çocukların da akılcı inançlara sahip birer birey olma eğilimini oluşturabilmektedir. 
Anne-babaların çocukları ile ilgili beklentilerin artması bireyin mükemmeliyetçiliğini tetikleyerek kaygı düzeyinin artmasına neden olur, bu durum da özel yetenekli çocuğun psikolojik süreçlerine zarar verebilir. Anne-babaların; ebeveynliğe ilişkin akılcı olmayan inançlarının ebeveynlik yetkinliklerini de etkileyebileceği düşünülmektedir. Ebeveynlerin akılc1 olmayan inançları ve ebeveyn yetkinliklerinin çocukları üzerindeki etkileri bu derece önemli olduğu düşünüldügünnde bu araştırma, özel yetenekli çocukların ebeveynlerinin akılcı olmayan inançları ve ebeveyn yetkinlikleri arasındaki ilişkinin ortaya konulması açısından önem arz etmektedir.

Sağlıklı çocuk yetiştirmek için sağlıklı davranan ve düşünen ebeveynlere ihtiyaç vardır. Sağlıklı düşünen ve davranan ebeveynler, sağlıklı düşünen ve davranan çocuklar yetiştirirler ve böylece sağlıklı aile oluşur. Toplumun temel yapı taşı olarak adlandırılan ailelerin sağlıklı olması sağlıklı toplumların oluşmasını sağlayacaktır. Alan yazın incelendiğinde özel yetenekli çocukların aile sistemi algıları ve öz kavramları (Şahin, 1995), ailelerin danışmanlık ihtiyaçları (Ihlamur, 2017), aile işlevselliği (Çalışkan, 2017), ebeveyn tutumları (Afat, 2013), sosyal destek algıları (Saranlı, 2017) gibi çalışmalar görülmekte olup özel yetenekli çocukların ebeveynlerinin akılcı olmayan inançları ve ebeveyn yetkinlikleri ile ilgili çalışmaya rastlanılmamıştır. Özel yetenekli bireylerin ebeveynleri ile ilgili bilimsel çalışmaların eksikliği göz önüne alındığında bu çalışmanın alandaki önemli bir eksikliği doldurması beklenmektedir.

\section{Yöntem}

$\mathrm{Bu}$ araştırmada, özel yetenekli çocukların ebeveynlerinin akılcı olmayan inançları ile ebeveyn yetkinliği arasında ilişki olup olmadığı; ayrıca özel yetenekli çocukların ebeveynlerinin akılı olmayan inançları ve ebeveyn yetkinliklerini çeşitli değişkenlere göre farklılaşıp farklılaşmadığı incelenmiştir. Araştırma modeli olarak ilişkisel tarama modeli kullanılmıştır.

\section{Çalışma Grubu}

Araştırmanın çalışma grubunu, 2018-2019 eğitim öğretim yılında ilkokul ve ortaokul düzeyinde olan özel yetenek tanısı almış ve Gaziantep ilindeki BİLSEM'e kayıtlı öğrencilerin ebeveynlerinden oluşmaktadır. Araştırma 
147 anne ve 126 baba olmak üzere toplam 273 ebeveynin katılımıla gerçekleşmiştir.

Ebeveyn ve çocuklara ait demografik özellikler Tablo 1 ve Tablo 2'de sunulmuştur.

Tablo 1. Ebeveynlere İlişkin Betimsel İstatistikler

\begin{tabular}{|c|c|c|c|}
\hline Cinsiyet & $n$ & $\%$ & \\
\hline Anne & 147 & 53.8 & \\
\hline Baba & 126 & 46.2 & \\
\hline Toplam & 273 & 100 & \\
\hline \multicolumn{4}{|l|}{ Çalışma Durumu } \\
\hline Çalışıyor & 211 & 77.3 & \\
\hline Çalışmıyor & 62 & 22.7 & \\
\hline Toplam & 273 & 100 & \\
\hline \multicolumn{4}{|l|}{ Toplam Aylık Gelir } \\
\hline $0-1600$ tl & 23 & 8.4 & \\
\hline 1601-3000tl & 28 & 10.3 & \\
\hline 3001-4500tl & 85 & 31.1 & \\
\hline 4501-6000tl & 49 & 17.9 & \\
\hline 6001-7500tl & 31 & 11.4 & \\
\hline 7501 ve üstü & 57 & 20.9 & \\
\hline Toplam & 273 & 100.0 & \\
\hline \multicolumn{4}{|l|}{ Eğitim Durumu } \\
\hline İlk ve ortaöğretim mezunu & 59 & 22 & \\
\hline Yükseköğretim mezunu & 214 & 78 & \\
\hline Toplam & 273 & 100.0 & \\
\hline \multicolumn{4}{|c|}{ Tablo 2. Çocuklara İlişkin Betimsel İstatistikler } \\
\hline Çocuk Sınıf Düzeyi & $\mathrm{n}$ & & $\%$ \\
\hline 2.sinif & 53 & & 19.4 \\
\hline 3.sinif & 47 & & 17.2 \\
\hline 4.sinif & 53 & & 19.4 \\
\hline 5.sinif & 32 & & 11.7 \\
\hline 6.sinif & 32 & & 11.7 \\
\hline 7.sinif & 28 & & 10.3 \\
\hline 8.sinif & 28 & & 10.3 \\
\hline Toplam & 273 & & 100.0 \\
\hline
\end{tabular}

Örneklem hacmi belirlenirken; Child (2006)'ya göre madde sayısının 4 ya da 5 katı; Tavşancıl (2010)'a göre madde sayısının en az 5 katı olmak üzere 7 ile 10 katı arasında olması araştırmanın örneklem hacmi için yeterlidir. Örneklem büyüklügü toplam ölçeklerin madde sayısının 6 katından 
daha fazla olduğu göz önüne alındığında; araştırmanın örneklem büyüklüğünün yeterli olduğu görülmektedir.

\section{Veri Toplama Araçları ve Geçerlilik-Güvenirlilik Analizleri}

Araştırmada, anne-babaların çocuk yetiştirme ve anne-baba olmayan ilişkin akılcı olmayan inançlarının değerlendirmek amacıyla Anne-Babaların Akılcı Olmayan İnançları Ölçeği (ABAOİÖ), anne ve babaların ebeveyn yetkinliklerini değerlendirmek amacıyla Ebeveyn Yetkinlik Ölçeği (EYÖ) ve araştırmacı tarafından oluşturulan Kişisel Bilgi Formu kullanılmıştır.

Anne-Babaların Akılcı Olmayan Ínançları Ölçeği (ABAOİÖ): Kaya ve Hamamcı (2010) tarafından anne-babaların akılcı olmayan inançlarının belirlemek amacıyla geliştirilmiştir. Toplam 29 maddenin yer aldığı ölçek iki alt boyuttan oluşmaktadır. Bu alt boyutlar; anne-babaların çocuklarıyla olan ilişkilerinde onlardan gerçekçi olmayan beklentilerini içeren "beklentiler" alt boyutu ve anne-babaların çocuk yetiştirmeyle ilgili mükemmeliyetçi düşünceleri içeren "mükemmeliyetçilik" alt boyutudur. Ölçeğin tüm maddelerinde, anne-babaların çocuk yetiştirmeye ve anne-baba olmaya ilişkin akılcı olmayan inançların belirlenmesine yönelik ifadeler bulunmaktadır. Toplamda 29 maddeden oluşan bu ölçeğin, ölçek maddelerinin 17'si (1, 2, 4, 6, 8, 9, 12, 14, 15, 16, 17, 18, 20, 23, 26, 27, 29) "beklentiler" alt boyutunu, 12'si de $(3,5,7,10,11,13,19,21,22,24,25,28)$ "mükemmeliyetçilik" alt boyutunu tanımlamaktadır.

Anne-Baba Akılcı Olmayan İnançlar Ölçeği "Tamamen Katılıyorum (5), Katılıyorum (4), Kararsızım (3), Katılmıyorum (2) ve Hiç Katılmıyorum (1)" şeklinde puanlanan 5'li likert tipi bir ölçme aracıdır. Akılcı Olmayan İnançlar Ölçeği, alt boyutlar bazında değerlendirilebilen bir araç olup, her bir alt boyuttan alınabilecek yüksek puan o alt boyuta ilişkin yüksek akılcı olmayan inancı tanımlamaktadır.

Anne-Baba Akılcı Olmayan İnançlar Ölçeği'nin geçerlik ve güvenirlik çalışması çocukların ilköğretim birinci kademeye devam eden 520 annebaba üzerinden veri toplanarak gerçekleştirilmiştir. Ölçeğin güvenirliği, ölçeğin beklentiler ve mükemmeliyetçilik alt boyutlarının iç tutarlılık katsayılarının hesaplanması ve test tekrar test yöntemleri ile incelenmiş olup ölçeğin güvenirlik çalışması kapsamında, "beklentiler" alt boyutunun test- 
tekrar test güvenirlik katsayısı .84 ve Cronbach Alfa iç tutarlılık güvenirlik katsayısı .89 bulunurken, "mükemmeliyetçilik" alt boyutunun test-tekrar test güvenirlik katsayısı .80, Cronbach Alfa iç tutarlılık güvenirlik katsayısı ise .86 bulunmuştur.

\section{Bu Araştırma Kapsamında ABAOİÖ İçin Yapılan Geçerlilik-Güvenirlik Analizleri}

Anne-Baba Akılcı Olmayan İnançlar Ölçeği'nin bu araştırmadaki veriler ile doğrulanması amacıyla alt boyutlar bazında Doğrulayıcı Faktör Analizi yapılmıştır. DFA sonucu "beklentiler" alt boyutuna ait faktör yükleri 0.32 ile 0.57 arasında elde edilmiştir. Uyum iyiliği değerlerini sağlayabilmek için beklentiler alt boyutunun 1. ile 2., 9. ile 10. ve 12. ile 17. maddeleri arasında modifikasyon yapılmıştır. DFA sonucu ölçeğin "beklentiler" boyutunda kabul edilebilir uyum iyiliği değerlerini sağladığı bulgusuna ulaşılmıştır. DFA sonucu "mükemmeliyetçilik" alt boyutuna ait faktör yükleri 0.41 ile 0.73 arasında elde edilmiştir ve yine DFA sonucu "mükemmeliyetçilik" boyutunda ölçeğin iyi uyum iyiliği değerlerini sağladığ bulgusuna ulaşılmıştır. DFA sonucunda "Beklentiler" ve "Mükemmeliyetçilik" alt boyutlarının gerekli koşulları sağladığı bulgusuna ulaşılmıştır.

Yine bu araştırma için güvenirlik analizleri yapılmış; "Beklentiler" alt boyutu için Cronbach Alfa iç tutarlılık güvenirlik katsayısı .816; "Mükemmeliyetçilik" alt boyutu için Cronbach Alfa iç tutarlılık güvenirlik katsayısı .869 olarak tespit edilmiş ve bu sonuçların kabul edilebilir düzeyde güvenilir olduğu bulgusuna ulaşılmıştır.

Ebeveyn Yetkinlik Ölçeği (EYÖ):Caprara, Regalia, Scabini, Barbanelli ve Bandura (2004) tarafından geliştirilen Ebeveyn Yetkinlik Ölçeği (EYÖ) Perceived Self Efficacy Scale (PPSE)'nin Türkçe'ye uyarlaması, geçerlik ve güvenirlik çalışmaları Demir ve Gündüz (2014) tarafından Malatya'da aile eğitimine devam etmekte olan 747 anne babadan oluşan araştırma grubu üzerinden gerçekleşmiştir. Özgün hali 12 maddeden ve tek faktörlü yapıdan oluşan ölçeğin üzerinde yapı geçerliği için açımlayıcı faktör analizi 339 anne ve 171 baba üzerinde olmak üzere 510 kişiden toplanan veriler üzerinden yapılmıştır. 
Öncelikli olarak çeviri çalışması sonucu dilsel eşdeğerliliği için ölçeğin hem İngilizce hem Türkçe formu İngilizce bilen ebeveynlere uygulanmış, iki form arasında yüksek bir tutarlılık bulunmuştur (.91).

Yapı geçerliliği için yapılan faktör analizi sonucunda ölçeğin \%55'ini açıklayan tek faktörlü bir yapı elde edilmiş, ayrıca ölçeğin özgün formunda yer alan maddelerden sadece birisi, kültürümüzle uyuşmadığı düşünülen, (.45'in altında kalan) ölçekten atılmış ve sonuç olarak ölçeğin uyarlanmış haliyle; 11 maddeden oluşan tek faktörlü bir yapı elde edilmiştir.

EYÖ'nin ölçüt bağıntılı geçerlik çalışmasında 60 anne ve 55 babadan oluşan gruba Genel Yetkinlik Ölçeği (GYÖ) uygulanmış ve bu ölçeğin toplam puanı ile EYÖ'nin toplam puanları arasındaki korelasyon .78 olduğu tespit edilmiştir. Ölçeğin güvenirliğini belirlemek için hesaplanan Cronbach Alfa iç tutarlık katsayısı 92 olduğu tespit edilmiştir. Ayrıca ölçeğin 60 anne ve 44 babadan oluşan gruba ikişer hafta arayla yapılan uygulaması sonucunda ise test-tekrar test güvenirlik sonucu ise .94 olarak tespit edilmiştir.

\section{Bu Araştıma Kapsamında EYÖ İçin Yapılan Geçerlilik-Güvenirlik Ana- lizleri}

Ebeveyn Yetkinlik Ölçeği'nin bu araştırmadaki veriler ile doğrulanması amacıyla Doğrulayıcı Faktör Analizi yapılmıştır. DFA neticesinde faktör yükleri 0.52 ile 0.78 arasında elde edilmiştir. Uyum iyiliği değerlerini sağlayabilmek için ebeveyn yetkinlik ölçeğinin 1. ile 3., 4. ile 5. ve 7. ile 9. maddeleri arasında modifikasyon yapılmıştır. DFA sonucu ölçeğin uyum iyiliği değerlerini sağladığı bulgusuna ulaşılmıştır.

Yine bu araştırma için güvenirlik analizleri yapılmış; Ebeveyn Yetkinlik Ölçeği için Cronbach Alfa iç tutarlılık güvenirlik katsayısı .887 olarak tespit edilmiş ve bu sonuçların kabul edilebilir düzeyde güvenilir olduğu bulgusuna ulaşılmıştır. 


\section{Verilerin Normalliği}

\section{Örneklem Sayısı Büyüklükleri}

Araştırmanın veri kaynağı olan örneklemi büyüklükleri veri analizlerinde istatistik seçimlerini etkilemektedir. Örneklem büyüklüğünün 30 ve üzerinde olduğu gruplarda verilerin normal dağılıma yakın dağılım gösterdikleri kabul edilmektedir. $\mathrm{Bu}$ araştırmada da veriler analiz edilirken iki ya da ikiden fazla gruplar arasındaki istatistik analizi seçiminde 30 ve üzerindeki örneklemin oluştuğu durumlarda parametrik istatistikler, 30'un altında kalan örneklem sayılarında ise non-parametrik istatistikler kullanılmaktadır (Büyüköztürk, 2016, s.8; Ural ve Kılıç, 2013, s.81).

\section{Merkezi Ĕ̆ilim Ölçüleri ile Normalliğin Kontrolü}

İdeal bir normal dağılımda; ortalama (Mean), ortanca (Median) ve tepe değerine (Mode) bakılarak normalliği kontrol edilebilir. Ortalama, ortanca ve tepe değer birbirlerine yakınlıkları derecesi, normal dağılım özellikleri sergileme konusunda bilgi verebilmekte; bu üç değer birbirlerine ne kadar yakınsa o derece normal dağılım özelliği sergilemektedir (Can, 2017, s.82). Ortalamanın (Mean), ortancadan (Median) büyük olması sağa çarpıklığı işaret ederken, ortalamanın ortancadan küçük olması sola çarpıklığı işaret eder. Bu noktada, ortalama, ortanca ve modun birbirine yaklaşması dağ1lım normalden uzaklaşmadığını göstermektedir (Büyüköztürk, 2016, s.40).

Tablo 3. Merkezi Eğilim Ölçüleri ile Normalliğin Kontrolü

\begin{tabular}{lllll}
\hline & $\mathrm{N}$ & Mean & Median & Mode \\
\hline Beklenti (AOI) & 273 & 71.29 & 71.00 & 68.00 \\
Mükemmeliyetçilik (AOI) & 273 & 35.79 & 36.00 & 36.00 \\
Ebeveyn Yetkinlik & 237 & 59.52 & 59.00 & 55.00 \\
\hline
\end{tabular}

\section{Skewness ve Kurtosis Değerleri ile Normalliğin Kontrolü}

$\mathrm{Bu}$ araştırmada verilerin normal dağılıp dağılmadığın belirlemek için Skewness ve Kurtosis değerlerine bakılmış; aşağıdaki tablo incelendiğinde Basıklık ve Çarpıklık değerlerinin -3 ile +3 arasında değer alması verilerin 
normal dağılıma sahip olduğunu göstermektedir (Kline, 2011; Chou ve Bentler, 1995; Hair vd., 2010; Bryne, 2010).

Tablo 4. Basıklık ve Çarpıklık Değerleri

\begin{tabular}{llllll}
\hline & $\mathbf{N}$ & Skewness & Std.Error & Kurtosis & Std.Error \\
\hline Beklenti (AOI) & 273 & -.209 & .147 & .091 & .294 \\
Mükemmeliyetçilik (AOI) & 273 & .039 & & -.219 & \\
Ebeveyn Yetkinlik & 237 & -.558 & & 2.186 & \\
\hline
\end{tabular}

\section{Normallik Testi ile Normalliğin Kontrolï}

Veri sayısının 30 ve üzere olduğunda Kolmogorov-Smirnov, 30'un altında kaldığı durumlarda Shapiro-Wilk değerlerine bakılması önerilmektedir (Ak, 2008, s.10). Tablo 5 incelendiğinde özel yetenekli çocukların ebeveynlerinden elde edilen verilerin, normal dağılıma uygun bir dağılım olduğu görülmektedir.

Tablo 5.Normallik Testi

\begin{tabular}{lllllll}
\hline Değişken & \multicolumn{3}{l}{ Kolmogorov-Smirnov } & \multicolumn{3}{l}{ Shapiro-Wilk } \\
\cline { 2 - 7 } & İ̀statistik & sd & $\mathrm{p}$ & İstatistik & $\mathrm{sd}$ & $\mathrm{p}$ \\
\cline { 2 - 7 } Beklentiler & .048 & 273 & $.200^{*}$ & .988 & 273 & .024 \\
Mükemmeliyetçilik & .030 & 273 & $.200^{*}$ & .996 & 273 & .653 \\
Ebeveyn yetkinlik & .044 & 273 & $.200^{*}$ & .970 & 273 & .000 \\
\hline
\end{tabular}

\section{Araştırma Bulguları}

Araştırmada; özel yetenekli çocukların ebeveynlerinin cinsiyet, çalışma durumları, çocuk okul kademeleri, toplam aylık gelire, eğitim durumlarına göre değişip değişmediğine ilişkin bulgulara yer verilmiş, Anne Baba Akılcı Olmayan İnançların Beklentiler alt boyutu ve Mükemmeliyetçilik alt boyutları ile Ebeveyn Yetkinlik Ölçeği arasında bir ilişki olup olmadığı incelenmiştir. Araştırmanın amaçlarına uygun istatiksel analizler yapılmış ve elde edilen sonuçlar açıklanmıştır. 


\section{Özel Yetenekli Çocukların Ebeveynlerinin Akılcı Olmayan İnançları ve} Ebeveyn Yetkinliklerinin Cinsiyet Değişkenine Göre Bulgularn

Tablo 6 incelendiğinde özel yetenekli çocukların ebeveynlerinin cinsiyet değişkenine göre ABAOIÖ Beklentiler alt boyutundan aldıkları puan ortalamaları arasında istatistiksel açıdan anlamlı bir farklılık tespit edilmiştir. Beklenti alt boyutu puan ortalamaları incelendiğinde annelerin $(X=72.06)$, babalara $(X=70.30)$ oranla daha anlamlı düzeyde daha yüksek puan ortalamalarına sahip oldukları tespit edilmiştir. Yine Tablo 6 incelendiğinde ABAOİ Mükemmeliyetçilik alt boyutu puanları arasında istatistiksel açıdan anlamlı bir farklılık görülmemektedir.

Tablo 6. Özel Yetenekli Çocukların Ebeveynlerinin Cinsiyet Değişkenine Göre ABAOİÖ Beklentiler ve Mükemmeliyetçilik Alt Boyutlarnndan Aldıklarn Puanlara İlişkin Bağımsız Grup T Testi Sonuçları

\begin{tabular}{lllllllc}
\hline & Grup & N & X & Sx & sd & t & p \\
\hline Beklentiler & Anne & 147 & 72.06 & 6.71 & 271 & 2.115 & $.035^{*}$ \\
& Baba & 126 & 70.30 & 6.19 & & & \\
Mükemmeliyetçilik & Anne & 147 & 36.30 & 8.42 & 271 & 1.081 & .281 \\
& Baba & 126 & 35.19 & 8.59 & & & \\
\hline
\end{tabular}

Tablo 7. Özel Yetenekli Çocuklarnn Ebeveynlerinin Cinsiyet Değişkenine Göre Ebeveyn Yetkinlik Ölçeğinden Aldıklarn Puanlara İlişkin Bă̆ımsız Grup T Testi Sonuçları

\begin{tabular}{lllllll}
\hline Grup & $\mathbf{N}$ & $\mathbf{X}$ & $\mathbf{S x}$ & $\mathbf{s d}$ & $\mathbf{t}$ & $\mathbf{p}$ \\
\hline Anne & 147 & 60.91 & 8.91 & 271 & 2.786 & $.006^{*}$ \\
Baba & 126 & 57.89 & 8.91 & & & \\
\hline
\end{tabular}

Tablo 7 incelendiğinde özel yetenekli çocukların ebeveynlerinin cinsiyet değişkenine göre Ebeveyn Yetkinlik Ölçeği'nden aldıkları puan ortalamaları arasında istatistiksel açıdan anlamlı bir farklılık tespit edilmiştir $(\mathrm{t}=2.786, \mathrm{p}<.05)$. Ebeveyn Yetkinlik Ölçeği'nden elde edilen puanlar karşılaştırıldığında annelerin $(X=60.91)$, babalara $(X=57.89)$ oranla anlamlı düzeyde daha yüksek puan ortalamalarına sahip oldukları görülmektedir. 
Özel Yetenekli Çocuklarn Ebeveynlerinin Akılcı Olmayan İnançları ve Ebeveyn Yetkinliklerinin Çalışma Durumları Değişkenine Göre Bulgular

Tablo 8 incelendiğinde özel yetenekli çocukların ebeveynlerinin çalışma durumlarına göre Anne-Baba Akılcı Olmayan İnançlar Ölçeği Beklentiler ve Mükemmeliyetçilik alt boyutlarından aldıkları puan ortalamaları arasında istatistiksel açıdan anlamlı bir farklılaşma bulunamamıştır.

Tablo 8. Özel Yetenekli Çocukların Ebeveynlerinin Çalışma Durumlarna Göre ABAOIÖ Beklentiler ve Mükemmeliyetçilik Alt Boyutlarından Aldıklar Puanlara İlişkin Bağımsız Grup T Testi Sonuçları

\begin{tabular}{llllllll}
\hline & Grup & N & X & Sx & sd & t & p \\
\hline Beklentiler & Çalışıyor & 211 & 71.10 & 6.52 & 271 & -.882 & .379 \\
& Çalışmıyor & 62 & 71.93 & 6.52 & & & \\
Mükemmeli- & Çalışyor & 211 & 36.13 & 8.55 & 271 & \multirow{2}{*}{1.242} & .215 \\
yetçilik & Çalışmyor & 62 & 34.61 & 8.29 & & & \\
\hline
\end{tabular}

Tablo 9.Özel Yetenekli Çocukların Ebeveynlerinin Çalışma Durumlarına Göre Ebeveyn Yetkinlik Ölçeğinden Aldıkları Puanlara İlişkin Bağımsız Grup T Testi Sonuçlart

\begin{tabular}{lllllll}
\hline Grup & $\mathbf{N}$ & $\mathbf{X}$ & Sx & sd & $\mathbf{t}$ & $\mathbf{p}$ \\
\hline Çalışıyor & 211 & 58.37 & 8.84 & 271 & -3.957 & $.000^{*}$ \\
Çalışmiyor & 62 & 63.40 & 8.59 & & & \\
\hline
\end{tabular}

Tablo 9 incelendiğinde özel yetenekli çocukların ebeveynlerinin çalışma durumlarına göre Ebeveyn Yetkinlik Ölçeği toplam puan ortalamaları arasında istatistiksel açıdan anlamlı bir farklılaşma tespit edilmiştir $(\mathrm{t}=-3.957, \mathrm{p}<.05)$. Ebeveyn Yetkinlik Ölçeği'nden elde edilen puanlar karşılaştırıldığında çalışan ebeveynlerin ( $X=50.37)$, çalışmayan ebeveynlere $(X=57.89)$ oranla anlamlı düzeyde daha düşük puan ortalamalarına sahip oldukları tespit edilmiştir.

Özel Yetenekli Çocuklarn Ebeveynlerinin Akılcı Olmayan İnançları ve Ebeveyn Yetkinliklerinin Çocuklarının Okul Kademeleri Değişkenine Göre Bulgularn

Tablo 10 incelendiğinde özel yetenekli çocukların ebeveynlerinin çocuklarının okul kademelerine göre Anne-Baba Akılcı Olmayan İnançlar Ölçeği 
Beklentiler ve Mükemmeliyetçilik alt boyutlarından aldıkları puan ortalamaları arasında istatistiksel açıdan anlamlı bir farklılaşma bulunamamıştır.

Tablo 10.Özel Yetenekli Çocukların Ebeveynlerinin Çocuklarının Okul Kademelerine Göre ABAOÏÖ Beklentiler ve Mükemmeliyetçilik Alt Boyutlarından Aldıkları Puanlara İlişkin Bağımsız Grup T Testi Sonuçları

\begin{tabular}{llllllll}
\hline & Grup & N & X & Sx & sd & t & p \\
\hline Beklentiler & İlkokul & 153 & 71.21 & 6.63 & 271 & -.221 & .825 \\
& Ortaokul & 120 & 71.39 & 6.40 & & & \\
Mükemmeliyetçilik & İlkokul & 153 & 35.16 & 8.17 & 271 & -1.380 & .169 \\
& Ortaokul & 120 & 36.59 & 8.87 & & & \\
\hline
\end{tabular}

Tablo 11.Özel Yetenekli Çocukların Ebeveynlerinin Çocuklarının Okul Kademelerine Göre Ebeveyn Yetkinlik Ölçeğinden Aldıkları Puanlara İlişkin Bağımsız Grup T Testi Sonuçları

\begin{tabular}{lllllll}
\hline Grup & $\mathbf{N}$ & $\mathbf{X}$ & $\mathbf{S x}$ & $\mathbf{s d}$ & $\mathbf{t}$ & $\mathbf{p}$ \\
\hline İlkokul & 153 & 59.41 & 9.23 & 271 & -.210 & .834 \\
Ortaokul & 120 & 59.65 & 8.77 & & & \\
\hline
\end{tabular}

Tablo 11 incelendiğinde özel yetenekli çocukların ebeveynlerinin çocuklarının okul kademelerine göre Ebeveyn Yetkinlik Ölçeği toplam puan ortalamaları arasında istatistiksel açıdan anlamlı bir farklılaşma bulunamamıştır.

Özel Yetenekli Çocukların Ebeveynlerinin Akılcı Olmayan İnançları ve Ebeveyn Yetkinliklerinin Toplam Aylık Gelir Değişkenine Göre Bulgular

Tablo 12. Özel Yetenekli Çocuklarn Ebeveynlerinin Toplam Aylık Gelir Değişkenine Göre ABAOÏÖ Beklentiler ve Mükemmeliyetçilik Alt Boyutlarından Aldıkları Puanlara İlişkin Tek Yönlü Varyans Analizi (ANOVA) Sonuçları

\begin{tabular}{lllllll}
\hline & Toplam Aylik Gelir & $\mathrm{N}$ & $\mathrm{X}$ & $\mathrm{Ss}$ & $\mathrm{F}$ & $\mathrm{p}$ \\
\hline Beklentiler & 0-3000 TL & 51 & 70.09 & 6.86 & 1.061 & .348 \\
& 3001-6000 TL & 134 & 71.52 & 6.35 & & \\
& 6001 TL ve üstü & 88 & 71.63 & 6.57 & & \\
\hline Mükemmeliyetçilik & 0-3000 TL & 51 & 33.56 & 10.12 & 2.301 & .102 \\
& 3001-6000 TL & 134 & 36.05 & 8.21 & & \\
& 6001 TL ve üstü & 88 & 36.67 & 7.75 & & \\
\hline
\end{tabular}

Tablo 12 incelendiğinde özel yetenekli çocukların ebeveynlerinin toplam aylık gelir düzeylerine göre ABAOİÖ Beklentiler ve Mükemmeliyetçilik 
alt boyutlarından aldıkları puanlar arasında fark olup olmadığını görmek için, ilişkisiz örneklemler için tek yönlü varyans analizi ile karşılaştırılmış, test sonucunda, toplam aylık gelir düzeyleri arasında istatistiksel açıdan anlamlı bir farklılaşma bulunamamıştır.

Tablo 13.Özel Yetenekli Çocuklarn Ebeveynlerinin Toplam Aylık Gelir Değiş̧kenine Göre Ebeveyn Yetkinlik Ölçeğinden Aldıkları Puanlara İlişkin Tek Yönlü Varyans Analizi (ANOVA) Sonuçları

\begin{tabular}{|c|c|c|c|c|c|c|c|}
\hline \multirow{4}{*}{\multicolumn{2}{|c|}{$\begin{array}{l}\text { Ebeveyn } \\
\text { Ölçeği }\end{array}$}} & $\begin{array}{l}\text { Toplam } \\
\text { Gelir }\end{array}$ & $\mathbf{N}$ & $x$ & Ss & $\mathbf{F}$ & $p$ \\
\hline & & $0-3000 \mathrm{TL}$ & 51 & 62.27 & 8.11 & 3.039 & .50 \\
\hline & & $3001-6000 \mathrm{TL}$ & 134 & 58.70 & 9.52 & & \\
\hline & & 6001 TL ve üstü & 88 & 59.17 & 8.49 & & \\
\hline
\end{tabular}

Tablo 13 incelendiğinde özel yetenekli çocukların ebeveynlerinin toplam aylık gelir düzeylerine göre Ebeveyn Yetkinlik Ölçeği'nden aldıkları puanlar arasında fark olup olmadığını görmek için, ilişkisiz örneklemler için tek yönlü varyans analizi ile karşılaştırılmış, test sonucunda, toplam aylık gelir düzeyleri arasında istatistiksel açıdan anlamlı bir farklılaşma bulunamamıştır.

Özel Yetenekli Çocukların Ebeveynlerinin Akılcı Olmayan İnançları ve Ebeveyn Yetkinliklerinin Eğitim Durumu Değişkenine Göre Bulgularn

Tablo 14. Özel Yetenekli Çocuklarn Ebeveynlerinin Eğitim Durumu Değişkenine Göre ABAOIÖ Beklentiler ve Mükemmeliyetçilik Alt Boyutlarından Aldıkları Puanlara İlişkin Bağımsız Grup T Testi Sonuçları

\begin{tabular}{llllllll}
\hline & Grup & $\mathbf{N}$ & $\mathbf{X}$ & $\mathbf{S x}$ & $\mathbf{s d}$ & $\mathbf{t}$ & $\mathbf{p}$ \\
\hline Beklentiler & İlk ve ortä̈̆gretim & 59 & 69.13 & 6.11 & 271 & -2.908 & $.004^{*}$ \\
& Yükseköğretim & 214 & 71.88 & 6.52 & & & \\
Mükemmeliyetçi- & İlk ve ortaöğretim & 59 & 31.86 & 7.16 & 271 & -4.122 & $.000^{*}$ \\
& Yükseköğretim & 214 & 36.87 & 8.53 & & & \\
\hline
\end{tabular}

Tablo 14 incelendiğinde özel yetenekli çocukların ebeveynlerinin eğitim durumu değişkenine göre Anne Baba Akılcı Olmayan İnançlanı Ölçeği Beklentiler ve Mükemmeliyetçilik alt boyutları toplam puan ortalamaları arasında istatistiksel açıdan anlamlı bir farklılaşma tespit edilmiştir. ABAOIÖ Beklentiler alt boyutundan elde edilen puanlar karşılaştırıld1- 
ğında ilk ve ortaöğretim mezunu ebeveynlerin $(X=69.13)$, yükseköğretim mezunu ebeveynlere $(X=71.88)$ oranla anlamlı düzeyde daha düşük puan ortalamalarına sahip oldukları tespit edilmiştir. ABAOİÖ Mükemmeliyetçilik alt boyutundan elde edilen puanlar karşılaştırıldığında ilk ve ortaöğretim mezunu ebeveynlerin ( $X=31.86)$, yükseköğretim mezunu ebeveynlere $(X=36.87)$ oranla anlamlı düzeyde daha düşük puan ortalamalarına sahip oldukları tespit edilmiştir.

Tablo 15. Özel Yetenekli Çocuklarn Ebeveynlerinin Ĕ̆itim Durumu Değişkenine Göre Ebeveyn Yetkinlik Ölçeğinden Aldıkları Puanlara İlişkin Bağımsız Grup T Testi Sonuçları

\begin{tabular}{lllllll}
\hline Grup & N & X & Sx & sd & t & p \\
\hline İlk ve ortaöğretim & 59 & 61.49 & 9.10 & 271 & 1.905 & .058 \\
Yükseköğretim & 214 & 58.97 & 8.94 & & & \\
\hline
\end{tabular}

Tablo 15 incelendiğinde özel yetenekli çocukların ebeveynlerinin eğitim durumu değişkenine göre Ebeveyn Yetkinlik Ölçeği toplam puan ortalamaları arasında istatistiksel açıdan anlamlı bir farklılaşma bulunamamıştır.

\section{Özel Yetenekli Çocukların Ebeveynlerinin Akılcı Olmayan İnançları ile Ebeveyn Yetkinlikleri Arasındaki İlişkinin Bulguları}

Tablo 16. Özel Yetenekli Çocukların Ebeveynlerinin Akılcı Olmayan İnançları ile Ebeveyn Yetkinlikleri Arasındaki İlişkiyi Gösteren Pearson Korelasyon Matrisi

\begin{tabular}{lllll}
\hline & Beklenti (AOI) & $\begin{array}{l}\text { Mükemmeliyetçi- } \\
\text { lik(AOI) }\end{array}$ & $\begin{array}{l}\text { Ebeveyn } \\
\text { kinlik }\end{array}$ & Yet- \\
\hline Beklenti (AOI) & 1 & & \\
\hline Mükemmeliyetçilik(AOI) & $.440^{* *}$ & 1 & \\
\hline Ebeveyn Yetkinlik & $.232^{* *}$ & -.061 & \\
\hline${ }^{* *} p<01$ & & &
\end{tabular}

Tablo 16 incelendiğinde özel yetenekli çocukların ebeveynlerinin akılcı olmayan inançlarının beklenti ve mükemmeliyetçilik alt boyutları ile ebeveyn yetkinlik boyutları arasında bir ilişki olup olmadığını ortaya koymak için basit doğrusal korelasyon işlemi yapılmış, akılcı olmayan inançlardan beklenti alt boyutu ile ebeveyn yetkinliği arasında pozitif yönde ve düşük düzeyde anlamlı bir ilişki olduğu görülmektedir $(r=0.232, p<.0 .01)$. 


\section{Tartışma}

\section{Özel Yetenekli Çocukların Ebeveynlerinin Akılcı Olmayan İnançları ve Ebeveyn Yetkinliklerinin Cinsiyet Değişkenine Göre Bulgularn ve İlgili Literatür Tartışması}

$\mathrm{Bu}$ araştırmada, özel yetenekli çocukların ebeveynlerinin cinsiyet değişkenine göre Anne-Baba Akılcı Olmayan İnançlar Ölçeği Beklentiler alt boyutundan aldıkları puan ortalamaları arasında istatistiksel açıdan anlamlı bir farklılaşma görülmektedir. Ebeveynlerin beklenti alt boyutu puan ortalamaları incelendiğinde annelerin, babalara göre daha fazla puan ortalamalarına sahip olduğu görülmektedir. Annelerin, babalara göre çocuklarıyla olan ilişkilerinde çocuklarından gerçekçi olmayan beklentilere daha fazla sahip olduğu söylenebilir. Mükemmeliyetçilik alt boyutlarından aldıkları puan ortalamaları arasında ise istatistiksel açıdan anlamlı bir farklılık bulunamamiştır.

Alan yazın incelendiğinde, benzer çalışmalar farklı bulgular ortaya koyabilmektedir. Starko (1991, s.70-76) tarafından; anne-babalık stresi ve anne-babaların akılcı olmayan inançlarının cinsiyete göre farklılaşıp farklılaşmadığı belirlemek amacıyla yapılan bir çalışmada ebeveynlerin akılcı olmayan inançlarının anne-baba olmalarına yani cinsiyete göre farklılaşmadığ1 tespit edilmiştir. Yine McDonalt (1993, s.43-44) tarafından annebabaların stresleri ile anne-babaların akılcı olmayan inançları ve evlilik uyumu arasındaki ilişkinin belirlenmesi amacıyla yaptığı araştırmada, ebeveynlerin akılcı olmayan inançları, cinsiyete göre istatistiksel açıdan anlamlı bir fark göstermemektedir. Bağcı (2013) tarafından, anne-babaların anne baba olmaya ilişkin akılcı olmayan inançlarının anne/baba olmaya yani cinsiyete göre farklılaşmadığ fından yapılan bir çalışmada, özel gereksinimli çocuklar olarak kabul edilen zihinsel engelli çocuk sahibi anne babaların akılcı olmayan inanç düzeylerinde anlamlı bir farklılaşma bulunamamıştır. Çekiç, Kaya ve Buğa (2019) tarafından yapılan çalışmada anne babaların akılcı olmayan inançları hem beklentiler hem de mükemmeliyetçilik boyutlarında cinsiyete göre farklılaşmadığı tespit edilmiştir.

$\mathrm{Bu}$ araştırmada, özel yetenekli çocukların ebeveynlerinin cinsiyet değişkenine göre Ebeveyn Yetkinlik Ölçeği'nden aldıkları puan ortalamaları 
arasında istatistiksel açıdan anlamlı bir farklılaşma tespit edilmiştir $(\mathrm{t}=2.786, \mathrm{p}<.05)$. Ebeveyn Yetkinlik Ölçeği'nden elde edilen puanlar karşılaştırıldığında annelerin $(X=60.91)$, babalara $(X=57.89)$ oranla anlamlı düzeyde daha yüksek puan ortalamalarına sahip oldukları tespit edilmiştir. $\mathrm{Bu}$ sonuçla ilgili olarak, annelerin çocukların bakımında daha aktif rol üstlenmesi ile ilgili olarak kendilerini çocukları hakkındaki hususlarda daha yetkin hissettikleri yorumu yapılabilir. Kültürel bağlamda ele alınd1ğında toplumumuzda, annelerin daha çok çocukları ve ev işleriyle ilgilendiği ve babaların daha çok bir işte çalışma, eve gelir sağlama görevleri göz önüne alındığında araştırmamızın ilgili bu bulgusu beklenti dahilindedir.

Alan yazın incelendiğinde, benzer çalışmaların farklı bulgular ortaya koyduğu görülmektedir. Telef (2013) tarafından yapılan bir çalışmada engelli çocuğa sahip ebeveynlerin öz-yeterliklerinde cinsiyete göre farkl1lık bulunamamıştır. Demir (2015) tarafından ebeveyn yetkinliğini demografik değişkenler açısından inceleyen bir çalışmada, ebeveynlerin cinsiyetlerine göre ebeveyn yetkinliği ölçeğinde babaların lehine daha yüksek düzeyde bir farklılaşmanın olduğu görülmektedir $(\mathrm{t}=-2.214 ; \mathrm{p}<.05)$. Hastings ve Brown (2002) tarafından özel gereksinimli grup olarak kabul edilen otizmli çocuğa sahip 26 anne ve 20 babanın ebeveyn yetkinlikleri incelenmiş, anlamlı farklılık bulunamamıştır.

\section{Özel Yetenekli Çocuklarn Ebeveynlerinin Akılcı Olmayan İnançlarn ve Ebeveyn Yetkinliklerinin Çalışma Durumlarn Değişkenine Göre Bulgula- rı ve İlgili Literatür Tartışması}

$\mathrm{Bu}$ araştırmada, özel yetenekli çocukların ebeveynlerinin çalışma durumlarına göre Anne-Baba Akılcı Olmayan İnançlar Ölçeği Beklentiler ve Mükemmeliyetçilik alt boyutlarından aldıkları puan ortalamaları arasında istatistiksel açıdan anlamlı bir farklılık bulunamamıştır. Yani; ebeveynlerin "çalışıyor" ya da "çalışmıyor" olması anne babalığa dair akılcı olmayan inançlarını etkilememektedir.

Alan yazın incelendiğinde, benzer çalışmalar araştırmanın bu bulgusunu destekler niteliktedir. Hocaoğlu (2016) zihinsel engelli çocuk sahibi anne babaların akılcı olmayan inanç düzeylerinin, çalışma durumuna göre farklılaşma düzeyleri incelenmiş ve anne babanın çalışıp çalışmamasının akılcı olmayan inançlar düzeyinde farklılaşma olmadığını tespit etmiştir. 
Özbiler (2017, s.27-39) tarafından yapılan çalışmada, Türkiye'nin Doğu Anadolu Bölgesindeki ilköğretim döneminde çocuğu olan annelerin sahip oldukları akılcı olmayan inançları çeşitli değişkenlere göre incelenmiş; çalışma durumları açısından istatistiksel açıdan anlamlı derecede farklılaşmadığı görülmüştür. Çekiç, Kaya ve Buğa (2019) tarafından yapılan çalışmada anne babaların akılcı olmayan inançları hem beklentiler hem de mükemmeliyetçilik boyutlarında çalışma durumlarına göre farklılaşmadı$\breve{g} 1$ tespit edilmiştir.

$\mathrm{Bu}$ araştırmada, özel yetenekli çocukların ebeveynlerinin çalışma durumlarına göre Ebeveyn Yetkinlik Ölçeği toplam puan ortalamaları arasında istatistiksel açıdan anlamlı bir farklılaşma tespit edilmiştir ( $\mathrm{t}=-3.957, \mathrm{p}<.05)$. Ebeveyn Yetkinlik Ölçeği'nden elde edilen puanlar karşılaştırıldığında çalışan ebeveynlerin $(X=50.37)$, çalışmayan ebeveynlere $(X=57.89)$ oranla anlamlı düzeyde daha düşük puan ortalamalarına sahip oldukları tespit edilmiştir. Bu sonuçla ilgili olarak, çalışmayan ebeveynlerin çocukları ile daha çok vakit geçirmeleri, onların bakımlarını üstlenmesi ve ayrıca kültürel bağlamda ele alındığında çalışmayan ebeveynlerin genelde anneler olduğu göz önünde alındığında araştırmanın bu bulgusu beklenti dahilindedir.

Alan yazın incelendiğinde yurtdışında yapılmış bir çalışmada, annenin sahip olduğu özellikler (yaşı, eğitimi, çalışma durumu, evlilik durumu ve aile geliri) ebeveyn yetkinliği arasında ilişki bulunmaktadır. Daha iyi eğitim almış, daha yüksek aile gelirine sahip annelerin daha yüksek ebeveyn yetkinliğine sahip oldukları sonucu elde edilmiş olup daha eğitimli annelerin yüksek ebeveyn yetkinliğine sahip olması çocuk gelişimi hakkında bilgiye ve etkili ebeveynlik stratejilerin sahip olma, çocuklar ile iyi bir etkileşim geliştirebilme ile açılanmaktadır (Coleman \& Karraker, 2000; Teti \& Gelfand, 1991). Coleman ve Karraker (2003, s.136) tarafından yapılan bir çalışmada ise, annenin çalışma durumu ile ebeveyn öz yeterlik algısı arasında bir ilişki bulunamamıştır.

Özel Yetenekli Çocuklarn Ebeveynlerinin Akılcı Olmayan İnançları ve Ebeveyn Yetkinliklerinin Çocuklarnın Okul Kademeleri Değişkenine Göre Bulguları ve İlgili Literatür Tartışması

$\mathrm{Bu}$ araştırmada, özel yetenekli çocukların ebeveynlerinin çocuklarının okul kademelerine göre Anne-Baba Akılcı Olmayan İnançlar Ölçeği Bek- 
lentiler ve Mükemmeliyetçilik alt boyutlarından ve Ebeveyn Yetkinlik Ölçeği'nden aldıkları puan ortalamaları arasında istatistiksel açıdan anlamlı bir farklılık bulunamamıştır. Çocukları ilkokul ve ortaokul kademelerinde olan ebeveynlerin anne babalığa dair akılcı olmayan inançlarında farklılık görülmemektedir.

Alan yazın incelendiğinde "çocuk okul kademesi" değişkenin ele alındığı herhangi bir araştırmaya rastlanılmamıştır. Bu anlamda "çocuk okul kademesi" değişkenin ele alınması alan yazına katkı sağlayacağı düşünülmektedir.

\section{Özel Yetenekli Çocuklarn Ebeveynlerinin Akılcı Olmayan İnançları ve Ebeveyn Yetkinliklerinin Toplam Aylık Gelir Değgişkenine Göre Bulgula- rı ve İlgili Literatür Tartışması}

$\mathrm{Bu}$ araştırmada, özel yetenekli çocukların ebeveynlerinin toplam aylık gelir düzeylerine göre Anne-Baba Akılcı Olmayan İnançlar Ölçeği Beklentiler ve Mükemmeliyetçilik alt boyutlarından ve Ebeveyn Yetkinlik Ölçeği'nden aldıkları puan ortalamaları arasında istatistiksel açıdan anlamlı bir farklılık bulunamamıştır.

Alan yazın incelendiğinde, anne babaların akılcı olmayan inançları ile ilgili benzer çalışmaların farklı bulgular ortaya koyduğu görülmektedir. Çevirgen (2016) tarafından yapılan bir çalışmada annelerin sosyoekonomik düzeyleri ile otomatik düşünceleri alt ölçekte 'umutsuzluğa yönelik' negatif yönde anlamlı bir fark bulunmuş olup sosyo-ekonomik düzey düştükçe otomatik düşünce düzeyi artmakta olduğu tespit edilmiştir. Hocaoğlu (2016) tarafından yapılan çalışmada da araştırma sonucunda, ailenin gelir düzeyi düştükçe anne babaların akılcı olmayan inançlarının arttı̆̆1 görülmüştür. Ackerman (1991) tarafından yapılan bir araştırmada ailenin yıllık gelirine göre akılcı olmayan inançların anlamlı bir şekilde farklılaştığını belirlemiştir. Üst ekonomik düzeydeki annelerin alt düzeydeki annelere göre akılcı olmayan inançlarının daha düşük olduğu tespit edilmiştir. Özbiler (2017), çalışmasında annelerin AAİÖ Beklenti boyutundaki puan ortalamalarında algilanan sosyoekonomik düzey ve ev hanesine düşen aylık gelire göre anlamlı bir farklılaşma bulunmamış iken Mükemmeliyetçilik boyutundaki puanları ortalamalarında algılanan sosyoekonomik düzeye ve ev hanesine düşen aylık gelire göre anlamlı dere- 
cede farklılaştığı bulunmuştur. Farklılaşmanın kaynağı karşılaştırılmalı olarak incelendiğinde ise kendisini düşük sosyo-ekonomik düzeyde alg1layan ve ev hanesine düşen aylık geliri yaklaşık 1000 Türk Lirası (TL) ile 2000TL arasında olan annelerin AAïÖ Mükemmeliyetçilik Alt Ölçeği puanları ortalamaları ( $\bar{x}=4.10, S S=.59)$, kendisini yüksek sosyo-ekonomik düzeyde algılayan ve ev hanesine düşen aylık geliri yaklaşık 4000 ve üzeri olan annelerin AAIÖÖ Mükemmeliyetçilik Alt Ölçeği puanları ortalamalarından $(\bar{x}=3.12, S S=.77)$ daha fazla olduğu belirlenmiştir. Mahigir, Kumar ve Karimi (2013) Hindistanlı ve İranlı kanser hastalarının akılcı olmayan inançlarını incelediği bir çalışmasında, yaptıkları çoklu karşılaştırma sonuçlarına göre, akılcı olmayan inançların yüksek ve düşük sosyoekonomik düzey ve yüksek ile orta-sosyo ekonomik düzey arasında farkl1laştı̆̆ını belirtmişleridir. Çekiç, Kaya ve Buğa (2019) tarafından yapılan çalışmada anne babaların akılcı olmayan inançlarında hem beklenti hem de mükemmeliyetçilik alt boyutunda istatistiksel anlamlı farklılık bulunmuştur. Beklentiler boyutu incelendiğinde; alt gelir grubundaki bireylerin beklentiler alt boyutu puanlarının üst gelir grubundaki ailelere göre anlamlı derecede daha yüksek olduğu sonucuna ulaşılmıştır. Diğer bir söyleyiş ile alt gelir grubunun üst gruba göre çocuklarından daha yüksek beklentiler içerisinde olduğu tespit edilmiştir. Mükemmeliyetçilik boyutu incelendiğinde; alt gelir grubundaki bireylerin mükemmeliyetçilik alt boyutu puanlarının üst gelir grubundaki ailelere göre anlamlı derecede daha yüksek olduğu sonucuna ulaşılmıştır. Diğer bir ifade ile alt gelir grubunun üst gruba göre daha fazla mükemmeliyetçi ebeveyn tutumları içerisinde olduğu görülmektedir.

Ebeveyn yetkinliği ile ilgili alan yazın incelendiğinde; Demir (2015), ebeveyn yetkinliğini demografik değişkenler açısından incelemiş; gelir düzeyleri farklı ebeveynlerin EYÖ'den elde edilen puanları arasında anlamlı farklılıklar bulunmuştur. Daha ayrıntılı incelendiğinde; aylık gelir düzeyi 500-1000 TL arasında olan anne babaların ebeveyn yetkinlik puanlarının diğer gelir düzeyi yüksek anne babalara göre daha düşük olduğu anlaşılmaktadır. Gelir düzeyi “500- 1000 TL" $(X=44.57)$ olan ebeveynlerin ebeveyn yetkinliği açısından gelir düzeyi "1000-2000 TL" $(X=54.42)$, “2000-4000 TL” ( $X=55.79)$, “4000 TL ve üzeri” ( $X=58.17)$, olan ebeveynlere göre daha alt düzeyde oldukları göze çarpmakta; puan ortalamaları 
karşılaştırıldığında gelir düzeyi düştükçe ailelerin ebeveyn yetkinlik puan ortalamalarının düştüğü görülmektedir.

\section{Özel Yetenekli Çocuklarn Ebeveynlerinin Akılcı Olmayan İnançlarn ve Ebeveyn Yetkinliklerinin Ĕ̆itim Durumu Değişkenine Göre Bulguları ve İlgili Literatür Tartışması}

$\mathrm{Bu}$ araştırmada, özel yetenekli çocukların ebeveynlerinin eğitim durumu değişkenine göre incelendiğinde yükseköğretim mezunu ebeveynlerin, ilk ve ortaöğretim mezunu ebeveynlere göre beklentiler ve mükemmeliyetçilik alt boyutlarında, anlamlı düzeyde daha fazla akılcı olmayan inançlara sahip oldukları tespit edilmiştir. Eğitim düzeyi yüksek olan ebeveynlerin, çocuklarından gerçekçi olmayan beklenti inançlara ve çocuk yetiştirmeleriyle ilgili mükemmeliyetçilik düşüncelerine daha fazla sahip olduğu görülmektedir. Ebeveynler, daima çocuklarının kendi yaşam koşullarından daha iyi yaşam koşullarına sahip olmalarını ve daha başarılı olmalarını istemektedirler. Daha yüksek eğitim düzeyine sahip ebeveynler ki bu ebeveynlerin yükseköğretim mezunu olduğunu göz önüne aldığımızda "daha mükemmel anne baba olmalıyım", "çocuklarımı hata yapmaktan korumalıyım", "iyi bir çocuk yetiştirmeliyim", "çocuğum benim yaşadığım sıkıntıları yaşamamalı", "çocuğumla ilişkim daima iyi olmalı", "çocuğuma daima örnek olmalıyım" gibi inançlara daha fazla sahip oldukları görülmekte ve hatta bu inançları gerçekleştirmek adına kişisel gelişim seminerlerine katılabilmekte, kurslara gitmekte, çocukları için gelişim, psikoloji vb. kitap okuyabilmektedirler.

Alan yazın incelendiğinde benzer çalışmaların farklı bulgular ortaya koyduğu görülmektedir. Hocaoğlu (2016) tarafından eğitim durumu değişkenine göre zihinsel engelli çocuk sahibi anne babaların akılcı olmayan inanç düzeylerinin farklılaşma durumu incelenmiş olup, annelerin beklenti düzeyleri ve babanın her iki alt boyuttan (beklentiler ve mükemmeliyetçilik) aldıkları puanların eğitim durumuna göre istatistiksel olarak anlamlı farklılaşma tespit edilmiştir. Yapılan bu araştırma sonucuna göre; okuryazar olmayan annelerin beklentilerinin, üniversite ve üstü mezuniyete sahip annelerin beklentilerinden yüksek olduğu belirlenmiştir. Babaların beklenti düzeylerine bakıldığında, sadece okur-yazar ya da ilkokul mezunu olan babaların beklenti düzeyleri, üniversite ve üstü mezuniyete sahip 
babaların beklentilerinden anlamlı derecede yüksek olduğu tespit edilmiştir. Babaların mükemmeliyetçilik durumlarına göre grupların durumu incelendiğinde, sadece okur-yazar ya da ilkokul mezunu olan babaların mükemmeliyetçilik düzeyleri, üniversite ve üstü mezuniyete sahip babaların mükemmeliyetçilik düzeylerinden anlamlı derecede yüksek olduğu tespit edilmiştir. Yine Ackerman (1991) tarafından yapılan araştırma bulgularına göre annelerin akılcı olmayan inançları onların eğitim düzeylerine göre anlamlı farklılaşmamaktadır. Çekiç, Kaya ve Buğa'nın (2019) çalışmasında ise akılcı olmayan inançların beklenti ve mükemmeliyetçilik alt boyutlarında istatistiksel anlamlı bir farklılaşma tespit edilmiştir.

Bu araştırmada, özel yetenekli çocukların ebeveynlerinin eğitim durumu değişkenine göre incelendiğinde Ebeveyn Yetkinlik Ölçeğinden aldıkları puan ortalamaları arasında anlamlı farklılaşma bulunamamıştır.

Alan yazın incelendiğinde Ogelman ve Topaloğlu (2014) tarafından yapılan çalışmada anne-babaların ebeveyn özyeterliği algıları, kendi eğitim durumlarına göre istatistiksel açıdan anlamlı bir farklılık göstermemiştir. Demir (2013) eğitim düzeyleri farklı ebeveynlerin Ebeveyn Yetkinlik Ölçeği'nden elde edilen puanları arasında anlamlı farklılıklar tespit edilmiş olup eğitim düzeyi arttıkça ebeveyn yetkinlik düzeyinin de artmakta olduğu görülmektedir.

\section{Özel Yetenekli Çocuklarn Ebeveynlerinin Akılcı Olmayan İnançlarn ve Ebeveyn Yetkinlikleri Arasındaki İlişkinin Bulgularn ve İlgili Literatür Tartışması}

$\mathrm{Bu}$ araştırmada, özel yetenekli çocukların ebeveynlerinin akılcı olmayan inançlarının beklenti ve mükemmeliyetçilik alt boyutları ile ebeveyn yetkinliği arasında bir ilişki olup olmadığını ortaya koymak için basit doğrusal korelasyon işlemi yapılmış, akılcı olmayan inançlardan beklenti alt boyutu ile ebeveyn yetkinliği arasında pozitif yönde ve düşük düzeyde anlamlı bir ilişki olduğu görülmektedir $(r=0.232, p<.0 .01)$. Özel yetenekli çocukların ebeveynlerinin; çocuklarından akılcı olmayan beklentileri arttıkça, ebeveyn yetkinliklerinin arttığ ebeveynlerin çocukları ile ilgili olarak onlardan beklentilerinin net olduklarını düşünmeleri ve kendilerini çocukları ile ilgili hususlarda anne ve baba olarak daha yetkin hissetmelerini sağlayabilmekte olduğu düşünüle- 
bilir. Ebeveynlerin çocukları ile ilgili hususlarda kendilerini "çok yetkin, ehliyetli ve başarılı olmaları" gerektiği düşünceleri aslında bir akılcı olmayan inanç olup ebeveynlerin bu yetkinlik algısına sahip olması onların aynı zamanda akılcı olmayan inanca sahip olduğunu gösterir.

Alan yazın incelendiğinde farklı bulgular görülmektedir. WebsterStratton ve Hammond'a (1988) göre ebeveynliğe ilişkin yaşanan depresyonun en büyük sebebi ebeveynlerin çocuklarına yönelik yanlış davranışları, inançları ve gerçekçi ve akılcı olmayan beklentileridir. Ebeveyn yetkinlik inançlarının artmasında, ebeveynlerin çocuklarıyla olumlu ilişkiler kurabilmesi, onların gelişimlerine katkıda bulunabilmeleri, çocuklarını iyi tanımaları ve onlara karşı gerçekçi ve daha akılcı beklentilere sahip olmalarına bağlıdır. Çocuklarına karşı akılcı olmayan beklentilere sahip olan veya çocuklarını yeteri kadar tanımayan ebeveynlerin, ebeveynlik konusunda başarısızlıklar ve sonrasında buna bağlı olarak depresyon yaşaması yüksek ihtimaldir (Akt. Demir, 2013). Ebeveynlerin duygusal stres düzeyleri ve düşük sorumluluk duygusunda ebeveyn yetkinliğinin ve ebeveynliğe bakış açılarının inceleyen bir bilimsel çalışmada; ebeveyn yetkinliği ve ebeveynliğe bakış açısı yüksek olan annelerin, daha az düzeyde depresyon yaşadıkları tespit edilmiştir (Gondoli ve Siverberg, 1997). Kohloff ve Barnett (2013) tarafından yapılan bir çalışmada, ebeveyn yetkinlik düzeyi ile annelerin depresyon düzeyleri arasında negatif bir ilişki olduğu tespit edilmiştir. Alan yazındaki bu çalışmalar bize, ebeveyn yetkinliği ile depresyon arasında negatif bir ilişki olduğunu göstermektedir. Telef (2013) tarafından yapılan bir çalışmada engelli çocuğa sahip ebeveynlerin özyeterlikleri ile psikolojik belirtiler arasındaki ilişkiler incelenmiş; araştırmanın sonucunda, ebeveyn öz-yeterliği ile psikolojik belirtiler arasında negatif yönde anlamlı ilişkiler olduğu tespit edilmiş olup Telef' in (2013) yaptığı bu çalışmanın sonucunda ebeveynlerin öz-yeterlikleri arttıkça psikolojik belirtilerin azaldığı söylenebilir.

\section{Sonuç}

$\mathrm{Bu}$ araştırma kapsamında, cevaplanması için araştırılan alt problemlere yönelik sonuçlar aşağıda özetlenmiştir:

1. Özel yetenekli çocukların ebeveynlerinin akılı olmayan inançlarindan beklentiler alt boyutu ve ebeveyn yetkinliklerinin ebeveyn 
cinsiyetine göre anlamlı farklılaştığı, fakat; akılcı olmayan inançlarından mükemmeliyetçilik alt boyutu cinsiyete göre farklılaşmadiğ1;

2. Özel yetenekli çocukların ebeveynlerinin akılcı olmayan inançları (beklentiler ve mükemmeliyetçilik) ebeveyn çalışma durumuna göre anlamlı farklılık göstermediği, fakat; ebeveyn yetkinliklerinin çalışma durumuna göre çalışmayan ebeveynlerin lehine anlamlı farklılık gösterdiği;

3. Özel yetenekli çocukların ebeveynlerinin akılcı olmayan inançları ve ebeveyn yetkinlikleri çocuklarının okul kademelerine göre anlamlı farklılık göstermediği;

4. Özel yetenekli çocukların ebeveynlerinin akılcı olmayan inançları ve ebeveyn yetkinlikleri toplam aylık gelirlere göre anlamlı farklılık göstermediği;

5. Özel yetenekli çocukların ebeveynlerinin akılcı olmayan inançları (beklentiler ve mükemmeliyetçilik) ebeveynlerin eğitim durumlarına göre anlamlı farklılaştığı, fakat; ebeveyn yetkinliklerinin eğitim durumlarına göre anlamlı farklılık göstermediği,

6. Özel yetenekli çocukların ebeveynlerinin akılcı olmayan inançlarının beklentiler alt boyutu ile ebeveyn yetkinliği arasında pozitif yönde ve düşük düzeyde anlamlı bir ilişki olduğu belirlenmiştir.

\section{Öneriler}

1. Bu çalışma ilkokul ve ortaokul düzeyinde olan özel yetenek tanısı almış ve Gaziantep ilindeki BİLSEM'e kayıtlı öğrencilerin ebeveynlerinden oluşmaktadır. Çalışmaya lise kademesi dahil edilerek ve örneklem sayıları arttırılarak ve hatta yükseköğretim düzeyindeki özel yetenekli çocukların ebeveynleri dahil edilerek çalışma kapsamlı hale getirilebilir.

2. Bu çalışma özel yetenekli çocukların ebeveynleri ile gerçekleştirilmiştir. Tanı almamış (normal gelişim gösteren) ebeveynler de dahil edilerek iki grup arasında karşılaştırmalar yapilabilir. 
3. Bu çalışma, nicel bir araştırma olup ebeveynlerle nitel bir araştırma yapılarak daha ayrıntılı bilgiler edinilebilir.

4. Bu çalışmada, özel yetenekli çocukların ebeveynlerinin akılcı olmayan inançları ile ebeveyn yetkinlikleri arasındaki ilişki incelenmiştir. Çalışmanın dışında kalan ve söz konusu kavramlarla ilişkisi olabileceği düşünülen farklı değişkenler kullanılarak alana katkı sunulabilir.

5. Çalışmadaki yararlı olunabilecek bağımsız ve bağımlı değişkenler eklenerek daha kapsamlı olarak gerçekleştirilebilir.

6. Özel yetenekli çocukların ebeveynlerinin (özellikle babaların ve çalışan ebeveynlerin dahil edilmesini sağlayarak), ebeveyn yetkinlik düzeylerini arttırıcı seminer, kurs, eğitim çalışmaları gerçekleştirilebilir. 


\title{
EXTENDED ABSTRACT
}

\section{Investigation of the Parents' Irrational Beliefs and Parental Self-Efficacy of Parents of Gifted Children}

\author{
Yunus Emre Aydın - Ahmet Buğa \\ Şahinbey Guidance and Research Center, Gaziantep University
}

Children with special needs; they are individuals who differ significantly from their peers in terms of individual and developmental characteristics and educational competencies. One of the children with special needs is considered to be gifted children. Gifted children are children who display superior performance in one or more talent or intelligence skills, exhibit high levels of performance, motivation and task responsibility in relation to their peers in creativity, arts and academic fields, and need appropriate opportunities to develop such skills (Milli Eğitim Bakanlığı, 2018; Kuzucu, 2014, p.471).

In addition to the pleasures of being a parent of a gifted child, it can be challenging and sometimes consumer. Compared to families with normally developing children, families of gifted children face different situations in many respects due to the developmental characteristics of their children. When parents are told for the first time that their children are gifted, they can live at the same time as pride and happiness; they may also be concerned about how to rearing a gifted child. Parents of many gifted children understand that their children's needs may be different from others, and may also feel that they are not equipped to cope with these difficulties. It is observed that the thinking styles and behaviors of gifted children are different from those that are typically expressed. Parents often describe their gifted children as difficult to cope with, strong wishes or coercive. When the families are asked for more detailed explanations, they are; stubborn, debater, patronizing, living in their own world, judgmental, perfectionist, self-criticizing and so on. adjectives (As cited in; Saranli, 2011; Davis and Rimm, 2004; Delisle, 2006; Webb et al., 2007). In this context, it can be said that parents perceive having a gifted child as a challenging task in a sense. As a matter of fact, this situation can be consi- 
dered as a questioning situation about the parents' own parental self efficacy.

Holloway, Suzuki, Yamamoto and Behrens (2005); stated that the development of parental efficacy is related to the quality of the relationship the parents have with their parents, the social support they receive from their spouses, relatives and other people in their immediate surroundings and their level of education. While parents with high parental competence tend to create more rational beliefs, such as cognitions that coexist with the belief in competence, such as hope, positive coping ideas, and selfaffirmation; parents with low self-efficacy beliefs may tend to have disastrous thoughts of self-blame and an overwhelming sense of ejaculation, that is to say, more irrational beliefs (Coleman and Karraker, 1998, p.70).

In this context in this research, it is investigated whether there is a relationship between gifted children's parents' irrational beliefs and parental self-efficacy. Additively, examined whether there is a differences between gifted children's parents' irrational beliefs and parental self-efficacy, according to some variables. Research model is carried out in survey research model from scientific research methods. The sample group, in the 2018-2019 academic year, it consists of the parents of primary and secondary school students registered to Sahinbey Science and Art Center in Gaziantep. Sample consists 147 mothers and 126 fathers totally 273 members. Personal information form, Parent Irrational Beliefs Scale and Parental Self-Efficacy Scale were used as data collections in this research. Research variables (gender, job status, level of students' grades, income, graduation status) were collected. In analysis of obtained data "statistical program for social science (SPSS)" package program was used. T-test (for unrelated samples), analysis variance for independent samples (ANOVA) were used. To determine whether there is a relationship between gifted children's' parents' irrational beliefs and parental self-efficacy simple linear correlation was used and showed in Pearson Correlation Matrix.

At the end of research, there were positive and low level of significant relationship found between irrational beliefs and parental self-efficacy of gifted children's' parents. When Parental Irrational Beliefs Scale is examined; mean scores of the Expectation subscale were examined, it was found that the mothers had significantly higher scores than the fathers. There is no statistically significant difference between the scores of Perfectionism 
sub-dimension according to gender. In order to see whether there is a difference between the scores obtained from Expectations and Perfectionism sub-dimensions according to monthly income level, it was compared with one-way analysis of variance for unrelated samples, and no significant difference was found between total monthly income levels. When the scores obtained from Expectations sub-dimension were compared, it was found that primary and secondary school graduates had significantly lower scores than those with higher education graduates. When the scores obtained from Perfectionism sub-dimension were compared, it was found that primary and secondary school graduates had significantly lower scores than those with higher education graduates.

When the variables were examined according to Parental Self-Efficacy Scale; it was seen that mothers had significantly higher mean scores than fathers and non-working parents had significantly higher mean scores than working parents. As a result of the analysis conducted to see whether there is a difference between the scores obtained from the Self-Efficacy Scale according to the total monthly income levels of the parents, no statistically significant difference was found between the total monthly income levels. Also no statistically significant difference was found between the total scores of according to the Self-Efficacy Scale educational background variable of the parents of gifted children.

\section{Kaynakça / References}

Ackerman, K. A. (1991). Irrational beliefs and parenting stress. Doctoral Dissertation. University of Alberta. Canada.

Afat, N. (2013). Çocuklarda üstün zekânın yordayıcı olarak ebeveyn tutumları. Hasan Ali Yücel Eğitim Fakültesi Dergisi, 20(1), 155-168.

Ak, B. (2008). Verilerin düzenlenmesi ve gösterimi. Kalaycı, Şeref (Yayına Hazırlayan) SPSS Uygulamalı Çok Değişkenli İstatistik Teknikleri içinde (s. 3-47).Ankara: Asil Yayın Dağıtım (2008).

Bağcı, C. (2013). Anne babaların akılcı olmayan inançlarının aile işlevi ve çocuklardaki davranış problemleri arasındaki ilişkinin incelenmesi. Yüksek lisans tezi. Gaziantep Üniversitesi Sosyal Bilimler Enstitüsü.

Bandura, A. (1982). Self-efficacy mechanism in human agency. American Psychologist, 32(2), 122-147. 
Byrne, B. M. (2010). Structural equation modeling with AMOS: Basic concepts, applications, and programming. New York: Routledge

Büyüköztürk, Ş. (2016). Sosyal bilimler için veri analizi el kitabı (22.Baskı). Ankara: Pegem Akademi

Canel, A. N. (2012). Evlilik ve Aile Hayatı.H.I. Durmuş (Ed.), İstanbul: AEP Uygulama ve Yaygınlaştırma Projesi.

Cavkaytar, A, (2017). Özel eğitime gereksinim duyan çocuklar ve özel eğitim (14. Bask1). İbrahim H. Diken (Ed.), Özel eğitime gereksinimi olan çocuklar ve özel eğitim içinde (s. 1-26). Ankara:Pegem Akademi Yayınları.

Child, D. (2006), The essentials of factor analysis (3rd Edition). London: Continuum.

Chou, C.-P. ve Bentler, P. M. (1995). Estimates and tests in structural equation modeling. In R. H. Hoyle (Ed.), Structural equation modeling: Concepts, issues, and applications (p. 37-55). ThousandOaks, CA, US: Sage Publications, Inc.

Coleman, P., ve Karraker, K. H. (1997). Self-efficacy and parenting quality: findings and future applications. Developmental Review, 18,47-85.

Coleman, P. K., ve Karraker, K. H. (1998). Self-Efficacy and parenting quality: findings and future applications. Developmental Review, 18, 30-46.

Coleman, P.K. ve Karraker, K.H. (2000) Parenting self-efficacy among mothers of school-age children: conceptualization, measurement and correlates. Family Relations, 49, 5-11.

Coleman, P.K. ve Karraker, K.H. (2003). Maternal Self-Efficacy beliefs, competence in parenting and toddlers' behavior and Developmental status. Infant Mental Health Journal, 24, 126-148.

Çalışkan, M. (2017). Üstün yetenekli çocuklara sahip ailelerin aile işlevselliği. Yüksek lisans tezi. Hasan Kalyoncu Üniversitesi Sosyal Bilimler Enstitüsü.

Çekiç, A., Kaya, I., ve Buğa, A. (2019). Anne babaların akılcı olmayan inançları ile yaşam doyumları arasındaki ilişkinin incelenmesi. Kastamonu Ĕ̆itim Dergisi, 27(2), 567-575.

Demir, S. ve Gündüz, B. (2014), Ebeveyn yetkinlik ölçeğinin uyarlanması: geçerlik ve güvenirlik çalışmaları. Mustafa Kemal Üniversitesi Sosyal Bilimler Enstitüsü Dergisi, 11(25), 309-322.

Demir, S. (2015), Ebeveyn yetkinliğinin demografik değişkenler açısından incelenmesi. Mustafa Kemal Üniversitesi Sosyal Bilimler Enstitüsü Dergisi, 12(29),133-148. 
Ellis, A., ve Bernard, M. E. (2006). Rational emotive behavioral approaches to childhood disorders: Theory, practice and research. (Der.). Springer Science \& Business Media.

Giallo, R., Kienhuis, M., Treyvaud, K. ve Matthews, J (2008) A psychometric evaluation of the parent self-efficacy in managing the transition to school scale, Australian Journal of Educational \& Developmental Psycho$\log y, 8,36-48$.

Gondoli, D.M ve Silverberg, S.B. (1997) Maternal emotional distress and diminished responsiveness: The mediating role of parenting efficacy and parental perspective taking. Developmental Psychology, 33(5),861-868.

Grolnick, W. S., Benjet, C., Kurowski, C. O. ve Apostoleris, N. H. (1997). Predictors of parent involvement in children's schooling. Journal of Educational Psychology, 89(3), 538-548.

Hair, J., Black, W. C., Babin, B. J. ve Anderson, R. E. (2010) Multivariate data analysis (7th ed.). Upper Saddle River, New Jersey: Pearson Educational International.

Hamamcı, Z. (2007). Anne babalara yönelik eğitim programlarının geliştirilmesi ve uygulanması. (Ed.) Yildız Kuzgun ve Zeynep Hamamcı Anne Baba Eğitim Programları içinde (s.1-26). Maya Akademi, Ankara.

Hastings, R. P., ve Brown, T. (2002). Behavior problems of children with autism, parental self-efficacy, and mental health. American journal on mental retardation, 107(3), 222-232.

Hauck, P.A. (1967). Rational Management of Children. Libra Publisher. New York. 14-38.

Hocaoğlu, Ö.H. (2016). Zihinsel yetersizliği olan çocuk sahibi anne ve babaların akılcı olmayan inançlarn ile çocuklarının sosyal becerileri ve problem davranışlarının karşılaştıılarak incelenmesi.Yüksek lisans tezi. Marmara Üniversitesi Eğitim Bilimleri Enstitüsü.

Holloway, S. D., Suzuki, S., Yamamoto, Y. ve Behrens, K. Y. (2005). Parenting self-efficacy among japanese mothers. Journal of Comparative Family Studies, 36(1), 61-76.

Hoover-Dempsey, K.V. ve Sandler, H. M. (1997). Why do parents become involved in their children's education? Review of Educational Research, $67(1), 3-42$.

Ihlamur, Ş. (2017). Üstün yetenekli çocuklara sahip ailelerin danışmanlık ihtiyaçlarının saptanması. Yüksek lisans tezi. İstanbul Ticaret Üniversitesi Sosyal Bilimler Enstitüsü. 
Joyce, M. (1995). Emotional reliefs for parents: Is rational emotive parent education effective? Journal of Rational- Emotive \& Behavior Therapy, 13, 55-75.

Kaya, İ. (2010). Anne-babaların akılcı olmayan inançları ölçeğinin geliştirilmesi:Psikometrik özelliklerinin incelenmesi. Yüksek lisans tezi. Gaziantep Üniversitesi Sosyal Bilimler Enstitüsü.

Kaya, İ. ve Hamamcı, Z. (2011). Anne-babaların akılcı olmayan inançları ölçeğinin geliştirilmesi. Kuram ve Uygulamada Eğitim Bilimleri, 11(3), 1149-1165.

Kline, R. (2011). Principles and practice of structural equation modeling, (2nd ed.). New York: The Guilford Press.

Kohloff, J. ve Barnett, B. (2013). Parenting self-efficacy: Links with maternal depression, infant behaviour and adult attachment. Early Human Development, 89(4), 249-256.

Köroğlu, E. (2014). Ruh sağllğınız için akılcı düşünme (4.Baskı). Ankara: HybYayıncilik

Kuzucu, Y. (2014). Küçükler için büyüklere: Çocuk ve ergen ruh sağlı̆̆g (4.Baskı). Ankara: Pegem Akademi.

Mahigir, F., Kumar, V. G., ve Karimi, A. (2013). The experience of irrational beliefs among Indian and Iranian cancer patients. Indian J FundamAppl Life Sci, 3, 592-599.

McDonalt, C.E. (1993). Parenting Irrational Beliefs and Marital Adjustment as Correlates Parenting Stress in Young Families. Unpublished Doctoral Dissertation. University of Alberta. Canada.

Millî Eğitim Bakanlığı Özel Eğitim Hizmetleri Yönetmeliği. (2018, 7 Temmuz) Resmîn Gazete (Sayı:30471) https://www.resmigazete.gov.tr/eskiler/2018/07/20180707-8.htm adresinden erişilmiştir.

Morgan, C.T. (1980). Psikolojiye giriş.(H.Arıcı ve diğerleri, Çev.) Ankara: Hacettepe Üniversitesi Psikoloji Bölümü Yayınları

Ogelman, H. G., ve Topaloğlu, Z. Ç. (2014). 4-5 yaş çocuklarının sosyal yetkinlik, saldırganlık, kaygı düzeyleri ile anne-babalarının ebeveyn özyeterliği algısı arasındaki ilişkilerin incelenmesi. Abant İzzet Baysal Üniversitesi Ĕ̆itim Fakültesi Dergisi, 14(1), 241-271.

Özbiler, Ş. (2017). Annelerin çocuklarına ilişkin akılcı olmayan inançlarının incelenmesi. Turkish International Journal of Special Education and Guidance \& Counseling, 6(2), 27-39. 
Pochtar, J.S. (2010). Maternal Irrationality, Stress, And Behavior, And Disabled Preschoolers' Functioning. St. John's University, Dissertation Degree of Doctor Of Psychology, New York.

Saranll, A.G. (2017). Üstün yetenekli çocukların ailelerine yönelik geliştirilen aile rehberliği programlarının etkililiğinin incelenmesi.Doktora tezi. Hacettepe Üniversitesi Sağlık Bilimleri Enstitüsü.

Starko, T.J. (1991). Parent Stress and Parent Irrational Beliefs: Mother Father Differences. Unpublished Master Dissertation. Universty of Alberta. 70-76.

Stimac, T. M. (1985). The impact of a cognitively-oriented parent education programon parents' rationality of beliefs and the family environment. Doktora Tezi. Division of Counselling and Educational Psychology. University of Oregon.

Şahin, A. (1995). Üstün yetenekli ve üstün yetenekli olmayan çocuklarm aile sistemi algıları ve öz kavramları: Karşılaştırmalı bir çalışma. Yüksek lisans tez. Boğaziçi Üniversitesi Sosyal Bilimler Enstitüsü.

Tavşancıl, E. (2010). Tutumların ölçülmesi ve SPSS ile veri analizi. Ankara: Nobel Yayınevi.

Telef, B. (2013). Engelli çocuğa sahip ebeveynlerin öz-yeterliklerinin ve psikolojikbelirtilerininincelenmesi. Erzincan Üniversitesi Ĕ̆itim Fakültesi Dergisi, 15(1), 33-49.

Teti, D. ve Gelfand, D. (1991). “Behavioral Competence Among Mothers Of İnfant in The First Year. The Mediational Role of Maternal Self- Efficacy", Child Development, 62. 918-929

Ural, A. ve Kılıç, İ. (2013). Bilimsel araştırma süreci ve spss ile veri analizi. Ankara: Detay Yayıncilik.

Webster, D.R. (2002).College students' perceptions of parentchildrelationships and their correlates: Explanatory style and empathy.Dissertation Abstracts International, 63(1-B), 571.

\section{Kaynakça Bilgisi / Citation Information}

Aydın, Y.E. ve Buğa, A. (2020). Özel yetenekli çocukların ebeveynlerinin akılcı olmayan inançları ve ebeveyn yetkinliklerinin incelenmesi. OPUS-Uluslararası Toplum Araştırmaları Dergisi, 15(22), 1373-1407. DOI: 10.26466/opus. 640449 